\title{
Travel Agency: A Critique of Anti-Trafficking Campaigns
}

\author{
Nandita Sharma
}

\begin{abstract}
This paper offers a critical evaluation of anti-trafficking campaigns spearheaded by some in the feminist movement in an attempt to deal with the issues of unsafe migrations and labour exploitation. I discuss how calls to "end trafficking, especially in women and children" are influenced by - and go on to legitimate - governmental practices to criminalize the self-willed migration of people moving without official permission. I discuss how the ideological frame of anti-trafficking works to reinforce restrictive immigration practices, shore up a nationalized consciousness of space and home, and criminalize those rendered illegal within national territories. Anti-trafficking campaigns also fail to take into account migrants' limited agency in the migration process. I provide alternative routes to anti-trafficking campaigns by arguing for an analytical framework in which the related worldwide crises of displacement and migration are for egrounded. I argue that by centering the standpoint of undocumented migrants a more transformative politics emerges, one that demands that people be able to "stay" and to "move" in a self-determined manner.
\end{abstract}

\section{Résumé}

Cet article propose une évaluation critique des campagnes contre la traite des femmes menées par certaines personnes appartenant au mouvement féministe, et cela dans une tentative pour résoudre les problèmes de migrations dangereuses et d'exploitation des travailleurs. J'examine comment les appels pour « arrêter la traite, spécialement des femmes et des enfants » sont influencés - et servent à légitimer - aux pratiques gouvernementales visant à criminaliser la migration volontaire des gens qui voyagent sans permission officielle. Je démontre comment le cadre idéologique anti- traite sert éventuellement à renforcer des pratiques plus restrictives en matière d'immigration, à la nationalisation des notions d'espace et de domicile et à criminaliser ceux qui sont rendus clandestins à l'intérieur des territoires nationaux. De plus, les campagnes contre la traite ne prennent pas en considération le peu d'influence des migrants dans le mécanisme de la migration. Je propose des voies alternatives aux campagnes contre la traite, en demandant la mise sur pied d'un cadre analytiquequi donnerait une place de première importance aux crises mondiales jumelées aux déplacements et à la migration. Je soutiens, qu'en ramenant le point de vue des migrants sans-papiers au centre de la discussion, on arriveà une politique qui acquiert un pouvoir de transformation et qui requiert que les gens aient le droit de « rester » et de « circuler » à leur gré.

\section{Introduction}

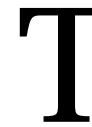

hereisno doubt that theissuesaddressed by anti-trafficking campaigns are in urgent need of attention: unprecedented levels of migration, unsafe migration practices; the exploitation of migrants; and the growing use of migrants as unfree, indentured, or even enslaved labour. H owever, anti-trafficking campaigns are unable to remedy these concerns. This is in part because the framing of these grave problems as one of "trafficking" or criminal "smuggling" assumes that the affected migrants are moved against their will and that the "trafficker" is the main culprit in their exploitation. ${ }^{1}$

Such a framing of the problem leaves many crucial questions unasked, questions such as: What are the conditions from which migrants are moving? How are most people 
able to migrate if not with the assistance of smuggling operations? What are the labour market options currently available for migrants, particularly undocumented ones? What are the factors that expose undocumented migrants to heightened vulnerability within nationalized labour markets? How are the (im)migration regimes of national states implicated in this?

I will try to show that far from helping migrants, especially women and children who are the main focus of many anti-trafficking efforts, anti-trafficking and/or anti-smuggling campaigns exacerbate the conditions that cause harm to migrants. They do so because one of the key underlying motives of these campaigns is to restrict the mobility of migrants, particularly undocumented movements of people. Indeed, deeply embedded within the anti-trafficking and anti-smuggling discourse and practice are anti-immigrant sentiments expressed best in the idea that migrants are almost (if not) always better off at "home." This is evident in both official and feminist definitions of trafficking.

Since feminist organizations are at the forefront worldwide in initiating and sustaining public campaigns against trafficking it is important to examine their assumptions. The most widely used definition of trafficking within such campaigns was jointly arrived at in 1999 by the Global Alliance Against Traffic in Women (GAATW), the Foundation Against Trafficking in Women, and the International Human Rights Law Group (IHRLG) based in theU.S. A significant aspect of it states that to be considered trafficked a person would have to be exploited, abused and deceived "... in a community other than the one in which such person lived at the time of the original deception, coercion or debt bondage." 2 There are two main problems with such a definition.

First, it makes the fact of migration the overriding concern and problem. Exploitation "away from home" is conceptualized as a separate problem from exploitative and/or untenable economic relations "at home." This structures knowledge of "home" in particular ways. Exploitation comesto beidentified with people'smovementsabroad and loses its moorings from the organization and expansion of capitalist social relationships wherein people's labour is alienated. In the process "home" is left naturalized and therefore depoliticized as a site where harm is also done to persons. As a result, the fact that capital is accrued and accumulated through employers' appropriation of a portion of workers' labour power is concealed. M oreover, the fact that people often move because they have been dislocated from their homes is left unaddressed by the romanticization of being "at home."

By making migration the problem, it is assumed that migration is something that isinherently damaging. AsBob
Sutcliffe has pointed out, "migration tends to be regarded as something which is both exceptional and undesirable" by both academic researchers and, I would add, by many migrant-rights activists. ${ }^{3}$ By problematizing migration itself, we are led away from a discussion of the socially organized conditions of both people's displacement and subsequent migration and the structuring of a contemporary Global Apartheid through national (im)migration regimes. The problematization of the migration of undocumented people also fails to address why certain people's mobilities are celebrated (those of tourists, intellectuals and members of non-governmental organizations (NGOs), for example) while those of Others is seen as detrimental.

Secondly, this influential definition of what constitutes trafficking fails to account for the reality of the current worldwide crisis of displacement, the proliferation of everincreasing restrictive immigration policies that prevent the majority of migrants from ever realizing full status in the countries and labour markets they migrate to, and the intensified expansion of global capitalist markets over the last quarter-century.

To address these important issues, I argue that we need to jettison the anti-trafficking and the anti-smuggling discourse and the national and international governmental practices that such discourses organize. Anti-trafficking campaigns need to be replaced with a political practice that actually listens to and privileges the standpoint of undocumented migrants. Undocumented migrants the world over have some fairly uniform and well-articulated demands: an end to practices of displacement, the opening of national border regimes and the labour markets organized through them, and an end to discrimination based on one's nationality. These are precisely the politics that have been taken up by the growing group of No Borders activists in the Global North and South.

An approach that is grounded in the material lived realities of migrants makes for a far more transformative practice, I believe, than an emphasis on the abusive practices within criminalized networks of smuggling in persons. Rather than calling for an end to trafficking or smuggling, taking the standpoint of migrants compels us to deal with the reality that such illicit movements are the only ones available to the majority of the world's displaced people.

As a preliminary attempt to begin our discussion of clandestine movements of people from the standpoint of migrants rendered "illegal," this paper is grounded in the accounts of women who arrived on four separate boats from China and landed on the west coast of Canada in the summer of 1999. All 599 migrants on these boats arrived without legal documentation and with the assistance of 
smugglers whom they pre-paid and/or became indebted to for their journeys. Officials of the Canadian state captured all 599 migrants. All those arriving on the last three boats, including children, were automatically detained in Canadian jails, some for well over a year.

I worked with some of these women migrants in my capacity as a member of a feminist organization committed to advocating for them. ${ }^{4}$ I was able to speak to a number of these women through the aid of a $\mathrm{M}$ andarin feminist interpreter who worked closely with those women from the first boat who were living outside of jails in the Vancouver, BC, area as well as those detained at the Burnaby Correctional Centre for Women. By drawing on their accounts of migration, the Canadian "justice" and immigration systems, and their thoughts on various strategies used by feminists to help them, I critically assess the conceptualization of trafficking in the fields of both governmental and feminist discourses. This, it is hoped, reveals some of the processes that make these women amongst the most vulnerable of people within Canadian society, particularly in its nationalized labour market. It may also help us to formulate better strategies to work in solidarity with undocumented migrants.

By looking at issues of power between advocates and migrants within feminist discourses of trafficking, my analysis examines some of the often-overlooked aspects of the question of trafficking in women. In particular, I critically examine both the official and feminist representations of "trafficked" "victims" and how anti-trafficking campaigns collude with national state as well as international political agendas that frame trafficking solely in terms of illegal migration. I further examine how the representation of undocumented women migrants solely as victims helps to legitimate the criminalization of their (and others') migrations. By discussing the ways in which migrant women's narratives challenge accepted notions of victimhood, I hope to bring to the fore the ways in which the international regime of nationalized borders creates the conditions for the proliferation of dangerous migrations.

M y findings will suggest that when moral panics of illegal migration, border control, and heightened criminality of migrants are deconstructed, a serious disjuncture emerges between women's accounts of migration and the dominant rhetoric of trafficking. Indeed, by critically evaluating the fissure between certain anti-trafficking campaigns and the experiences of undocumented women we find that women within the two groups are often not fighting for the same thing. This paper, therefore, asks whether it is possible that the actual intended utility of anti-trafficking campaigns is not to serve the interests of migrants but to function as an arm of border control? If so, the issue is really how it has chosen to represent its objectives as humanitarian, thereby sustaining support for an inherently oppressive project from many progressive people.

\section{Global Processes of D isplacement and Cross-Border Migration}

Today, accelerating processes of globalization are leading to an unprecedented level of displacement. Practices that dislocate people include those that destroy and/or immiserate rural economies; mega- "development" projects, such as hydroelectric dams; resource extraction projects of mining, drilling, and excavating; adoption of market-centred economies; trade liberalization; privatization; the structural adjustment programs of international lending institutions; and war and militarization. Practices such as these have been shown to destroy both livelihoods and ecological integrity and have led to a dramatic rise in both the absolute and relative rise of poverty and homelessness the world over. ${ }^{5}$

The displacement of people is organized through the co-ordinated interplay of actions taken by capitalist investors, national state leaders, and members of international bodies. Investors continuously "prowl the globe," to use Cynthia Enloe's term, and use past and new rules of international investment for opportunities to accrue profits and cheapen labour forces. ${ }^{6}$ Currently, more people than ever before have been "embraced" by capitalism through the destruction of what was left of their non-market self-sufficiency. Thisis, perhaps, the core of themeaning of processes of globalization: the planetary hegemony of capitalist social relations.

$\mathrm{N}$ ational states fund both privateand public projects that displace people. For example, the Canadian state is a major funder of the largest dam project in the world: the almost completed ThreeGorges Dam Project on the Yangtze River in China. ${ }^{7}$ Private capitalist interests based in Canada are also heavily involved. M any of the engineering designs, computer systems, and turbine generators for the dam are being provided by firms operating in Canada. ${ }^{8}$ It is estimated that this dam has al ready displaced and will continue to displace upwards of two million small-scale farmers and other residents. ${ }^{9}$

International bodies, such as the International M onetary Fund (IM F) and the World Bank (WB), not only fund these mega-development projects but with other bodies, like the World Trade Organization (WTO), enforce the spread of capitalist social relations, require austerity programs (often to be implemented by all-too-willing national governments), and impose trade sanctions. Together, capital investors, national states, and international governing regimes bring to life Margaret Thatcher's old campaign slogan that "there is no alternative" to capitalist market development. 
The result? The displacement of hundreds of millions of people both outside of and within nationalized spaces. Within China alone, those displaced by the Three Gorges Dam are joined by an estimated 200 to 300 million people migrating within the country in the search for new livelihoods because of the turn towards the capitalist marketplace in both the countrysideand the city. The dual process of proletarianization and urbanization is taking place throughout Asia, Eastern Europe, Africa, and South and Central America.

Studies by urban geographers document how by the year 2005 at least half of the world's population will be living in urban centres. ${ }^{10}$ This will be a first in human history. Yet, urban centres have proven incapable of providing a livelihood to the majority of people displaced from rural communities. A recent ILO study, "Global Employment Trends," estimates that about 180 million people throughout the world are completely jobless. ${ }^{11}$ According to the same report, this is a growth of over 20 million unemployed persons since 2000. H undreds of millions more are underemployed or employed in informal economies.

One major consequence of the crisis of displacement is the exponential increase in levels of cross-border move ments of people. In the year 2000, over 150 million people were engaged in international migration. ${ }^{12}$ This is a doubling of the figures from the mid-1980s and this number is expected to double again by the end of this decade. Significantly, those countries which have experienced the highest rate of direct capitalist investment in the manufacturing and service sectors are among those that also sustain the highest rates of emigration. ${ }^{13}$

To put this into perspective, about 1.5 billion peoplehave crossed nationalized borders over the last decade alone. In absolute numbers, which are arguably important, this rate of migration is more than that which occurred in the nineteenth and early twentieth centuries: the great "age of mass migration." ${ }^{14}$ Significantly, in contrast to the migrations of a century ago when most migration was out of Europe, most cross-border migrants today are from the Global South. ${ }^{15}$

Contemporary migrations from Global South to N orth reflect the very real concentration of wealth in the North. One indicator of this is the United $\mathrm{N}$ ations Development Plan's estimate that at least $\$ 500$ billion in wealth is transferred from the South to the North every year..$^{16}$ Indeed, spatial disparities in prosperity and peace are the driving force of contemporary migrations. It is well documented that one of the main reasons migrants move towards the Global N orth is for the economic advantages that employment and remittances of wages in highly valued currencies may provide for them and their communities. ${ }^{17}$
The response to such spatial disparities by national states within the Global North (where 70 per cent of all transnational corporate headquarters and the United Nations (UN), theIM F, WB, and WTO areheadquartered) has been the imposition of draconian immigration restrictions. $A$ plethora of these have been put into place. The Schengen Treaty, signed by European Union (EU) members in 1985, neutralized internal borders between member states, thereby enabling the free circulation of goods, capital, services, and people classified as citizens. Alongside these border liberalizations, attempts to reinforce the external borders of the EU have been madethrough greater policing and surveillance levels on the outer rim of the EU and through the harmonization of the migration policies of member states. By presenting the migration of non-EU citizens as a major "problem," the Schengen treaty has created a consciousness, if not actual practice, of a fortified Europe buttressing itself against its non-European Others.

Theharmonization of restrictivenational (im)migration regimes extends beyond Europe and covers the whole of the Global N orth. ${ }^{18}$ In Canada since the early 1970s, the period widely regarded as the start of the latest phase of globalization, it has become increasingly difficult to immigrate to Canada, that is, to move to Canada and receive permanent residency status. Each successive change to Canada's Immigration and Refugee Act, culminating in a dramatic overhaul in June of 2002, has had the result of limiting the numbers of peoplewho are eligibleto beadmitted as permanent residents - the first step to gaining formal citizenship status.

Despite these changes, however, people keep coming. And of course they will. In every period of known human history, people have migrated from where life-sustaining resources are not available to where they are. People have crossed oceans, deserts, and mountains and will continue to do so. So if ever more restrictive immigration policies in the North have not actually restricted people's migrations, then what exactly are they intended to accomplish? The answer that emerges must be: a decline in the number and proportion of people coming as immigrants (with permanent residency status) and an increase in the numbers and proportion of migrants categorized by national states as either indentured temporary (or "migrant") workers or as so-called "illegals." 19

I argue that this is not a coincidence but a highly predictableand intended outcome of the current accelerating processes of growing displacement and migration. ${ }^{20}$ Border controls - and the moral panics that drive them - have very little to do with stopping movements of people. ${ }^{21}$ Instead, they work to make those who do cross the line incredibly vulnerable within the spaces defined as "belonging" to members of the "nation" and protected by "their state." In 
other words, ever-increasing restrictive immigration policies do not work to restrict people's movements but to create a group of people completely vulnerable to exploitation in theworkplace; a population of workers that benefits employers by providing them a cheapened and weakened alternative to "legal" workers. ${ }^{22}$

Such restrictions are particularly significant for women migrants. W omen, especially those from the Global South, have al ways had the most legal barriers placed against their ability to access and gain full, legal status within the Global North. This is often due to the fact that official entrance criteria rely upon and replicate the unequal access that women have had to formal education, skills training, and capital. ${ }^{23} \mathrm{~W}$ omen generally come to the $\mathrm{N}$ orth classified either as "dependents" of their husbands or fathers, as "temporary" indentured migrant workers or as "illegals." Most come in the latter two categories and as a result are rendered highly vulnerable in the labour market and in all other parts of their lives. ${ }^{24}$

The retooling of immigration policies therefore needs to beanalyzed as part of how labour markets within the Global North have been restructured in an attempt to once again be "attractive" to capitalist investors. ${ }^{25}$ This is, of course, unsurprising, given that women of colour currently embody a "competitive advantage" of capitalists seeking the highest return of profit from their investments. (Im) migration policies that reproduce women's labour market inequality reflect the gendered international division of labour that makes use of Third W orld and negatively racialized immigrant women as the most "flexible" workforce in the restructuring of capitalism both globally and within nationalized labour markets. Further restricting women's access to permanent status, particularly within the context where more women have become international migrants than ever before, is therefore a strategy for re-attracting capital to the country. ${ }^{26}$

The use of illegalized workers and indentured, migrant workers, including sex workers, has historically been - and remains now - an integral part of how capitalism is donein Canada and cannot rightly be perceived to be an aberration from the establishment of liberal democracy for "citizens." ${ }^{27}$ Instead, the re-emergence of these forms of labour exploitation and the fact that they are both organized and legitimated through Canadian (im) migration policies area reflection of a growing Global A partheid based on nationality. ${ }^{28}$

It is the internationally recognized and legitimated "right" of national states to place people within differential categories of membership in the "nation" that allows them to legally deny permanent or citizenship status to the vast majority of migrants. ${ }^{29}$ In fact, the creation of disparities between citizens and non-citizens is how concepts of "citizenship" work within the global system of national states. In reality, throughout the history of national states there have never existed "citizens" without the concomitant existence of those who have been O thered as "non-citizens." 30 They exist as mutually constitutive state categories.

Employers benefit enormously from using people as "migrant" or "illegal" workers. Many employers deliberately employ those with a non-permanent and non-citizen status to maximize control and profits. ${ }^{31}$ That is, it is not just a case of their being the only labour force available though that can be a factor. Instead, there are specific advantages to the employer if the worker is a migrant. Employers therefore work with the state to ensure a steady supply not just of any bodies but of bodies branded as "temporary" or as "illegal." "32 Citizenship politics, then, by denying a large number of people any rights and entitlements through their categorization as non-citizens, operate as tools of labour market restructuring. ${ }^{33}$

It is within this context that we need to discuss the issue of trafficking or smuggling in women. Indeed, as Anderson and $\mathrm{O}^{\prime}$ Connell Davidson point out, "the factors behind demand for migrant labour pose problems for notions of coercion and consent that those engaged in debates around trafficking must engage with." ${ }^{34}$ Realizing the crucial importance of the creation and maintenance of juridico-legal national borders enables us to analyzeimmigration regimes that foster the legal, economic, social, and physical vulnerability of women who come to be labeled as "trafficked."

It is important, in this regard, to note that anti-trafficking measures target only those moving without state permission, sans papiérs, assuming that those moving with legal documentation are not deceived, coerced, or abused, either in their own journeys or within the countries they come to immigrate to. Anti-trafficking campaigns, however, do not address the denial of nationality status as the main factor in creating conditions of vulnerability of undocumented migrants. Stopping such movements or "reintegrating trafficked victims" to their "home society" is the overriding goal.

\section{Criminalizing Undocumented Border Crossers}

$\mathrm{N}$ ational states in the Global $\mathrm{N}$ orth and international bodies, such as the EU or the UN, have discursively and legally associated trafficking with illegality and with organized crime. Borders have been presented as a site through which criminality is able to seep into the national state. In this respect, the implementation of border protection schemes has been endorsed as a pivotal measure to regain "control" over O ur space. As the President of the EU stated recently, "[b]etter management of the Union's external border con- 
trols will help in the fight against terrorism, illegal immigration networks and the trafficking in human beings." ${ }^{35}$

This is similar to the approach adopted by the UN. It its 2000 Protocol to Prevent, Suppress and Punish Trafficking in Persons, Especially Women and Children and the 2000 Palermo Protocol A gainst the Smuggling of M igrants, the issues facing undocumented migrants have been situated not within the apparatus dealing with issues of human rights but within theConvention Against T ransnational Organized Crime. This has led some to argue that the last concern of such measures is the migrant her/himself.

Indeed, as Francois Crépeau states: "[t]he Protocol Against the Smuggling of M igrants is aimed at combating what all countries qualify as a 'plague': the uncontrolled immigration that is not selected according to the needs and interests of the receiving State... ${ }^{36}$ Indeed thetwo Protocols against trafficking and against smuggling need to be understood as part of thenext step in the establishment of barriers preventing large numbers of migrants from moving with any semblance of entitlements and rights.

The UN Protocols extend the border control projects of the Northern national states that have imposed visas for most, if not all, countries in the Global South and Eastern Europe, carrier sanctions, "short stop operations," training of airport or border police personnel, lists of "safe third countries," lists of "safe countries of origin," readmission agreements with neighbouring countries that form a "buffer zone," immigration intelligence sharing, reinforced border controls, armed interventions at sea and military interventions. ${ }^{37}$

Thereturn "without undueor unreasonabledelay" of the so-called trafficked or smuggled migrant remains the ultimate objective of the Palermo Protocol (article 18). Its main objective is not the protection of individual migrants but both the containment of their movement and their exposure to heightened vulnerability once residing within a particular national state. Cynthia M eillon has pointed out that this objective also appears to dominatethe UN'sBeijing Plus Five document (a follow-up to examine whether governments have fulfilled the commitments they made when signing the 1995 Beijing Declaration and Platform for Action). ${ }^{38}$ Far from trying to protect people harmed during their illicit migrations, theUN'stwo Protocolsand its Beijing Plus Five document provide measures for national states to combat undocumented migrations. Hence, assistance to national governments to "reintegrate" (i.e., deport) supposed victims of trafficking to the countries they have left (paragraphs 70b and 96c) is their overarching concern.

Importantly, unlike many UN declarations and agreements, the ones addressing trafficking and smuggling have been integrated into many national states policies. Canada has included Article 6 of the criminalization of smuggling activities of the Palermo Protocol in its new, and erroneously named, I mmigration and Refugee Protection Act. This new Act provides for a possibility of imprisonment for a maximum of two years on a summary conviction or fourteen years on indictment for smuggling less than ten persons and life imprisonment for smuggling a group of ten persons or more or for disembarking illegal migrants at sea. ${ }^{39}$

Significantly, the Canadian state does not have to prove that harm to persons or damage to property took place in order to secure a life sentence: the simple act of moving ten or more people across borders without state permission is sufficient. Indeed, immigration lawyers and other advocates for migrants have informally reported to me that the Canadian government isattempting to prosecutepeoplefor acts of smuggling (which includes the securing and passing of forged identity documents) engaged in by family members or NGOs. The state has made it clear that it can and will prosecute cases in which people were smuggled for humanitarian reasons under its new law.

Crépeau argues that such a law-and-order approach to dealing with undocumented migrations is particularly hypocritical.$^{40}$ The drafters portray the smuggled migrants as potential victims, not to actually assist them in their survival strategies but to garner legitimacy for the state's criminalization of migrants who use smugglers and the scapegoating of the latter as the cause of people's migrations. If certain migrants can be labeled as "trafficked," it seems, then specific policy measures to initiate deportation measures can be mobilized with little outcry from the general population and even some (im)migrant advocates.

Such legitimation strategies are perhaps most evident in regard to women who are identified as "victims of trafficking." This is especially the case for women working in the sex industry. Deborah Brock argues that, "[b]y clamping down on prostitution involving migrant women, the police and the Canadian legal system are presented as actually working in the best interests of the women involved, by protecting them from traffickers." ${ }^{41} \mathrm{~K}$ ara Gillies adds that, "[It is therefore of] ... great concern that... [recent ]changes to immigration and refugee law make specific references to the trafficking of women and children for sexual purposes as part of the platform for why we need to tighten our borders. It seems to me a very deliberate ruse to garner support from otherwise liberal thinking people for an extremely [racialized] and regressive immigration policy." ${ }^{42}$

The priority of establishing law and order at the border evident within national and international practices further exacerbates the conditions that cause harm to undocumented migrants. Making it increasingly costly for smugglers to move people, by militarizing and patrolling routes 
of clandestine migrations or by making the legal penalties of smuggling greater, has not proven effective in stopping people's migrations. Instead, such measures only lead to higher fees being charged and to even more unsafe routes of migration. By criminalizing any support offered to assist a person's undocumented movement across nationalized borders, the possibility of not-for-profit groups becoming involved in moving people also becomes highly fraught with danger.

By ignoring the reasons - and responsibility - for why people begin their clandestine journeys and by making the stopping of smuggling its top priority, the "get tough on traffickers and/or smugglers" approach further serves the ideological purpose of wholly eclipsing the fact that people's displacement is caused by economic, political, or social forces controlled by the complex interactions of transnational corporations, national states, and international bodies. Moreover, the reality that, aside from profit-making smuggling rings, there is very little ability for people to migrate, is ignored.

As a result of the failure to address these systemic causes and effects, the actual lives of migrants are made unimportant. Indeed, it can be argued that anti-trafficking campaigns, by relying upon and further mobilizing nationalist ideas of "homelands," actually work to strengthen the state, strengthen nationalist ideas of entitlement for "citizens" and punishment for "non-citizens" and strengthen the profitmaking capacities of capital investors. Through these efforts, legitimacy is gained for securing a growing group of people who through their classification as "illegals" can be exploited precisely because of their lack of nationality status.

In this there is collusion between anti-trafficking NGOs who wish to define women migrants moving sans papiérs as "trafficked" and the state and regional and international bodies who also want to do so. Determining that a particular woman has been trafficked enables the state to deport the woman while appearing to be helping her. Of course it does not hurt the funding opportunities for the NGOs embarking on anti-trafficking campaigns either since continued funding often rests on producing a good record on how many women have been "rescued" by the group.

\section{The Trope of Violence within Anti-T rafficking Campaigns}

The discourse that associates trafficking with violence is perhaps key to its legitimacy as the dominant analytic frame for comprehending certain people's migrations, especially those of women and children. As Rutvica Andrijasevic states,
... the topic of violence points to the complexity of the production of thevictimhood narrative: itsplot lendsitself for manipulation because it is already available within the mainstream discursive scenario on trafficking but, simultaneously, its appropriation feeds into and further sustains the dominant rendering of trafficking in terms of crime and violence. ${ }^{43}$

The appropriation of the experiences of violence had by migrants works to feed into and sustain the dominant rendering of trafficking in terms of crime and violence. ${ }^{44}$ Theuse of previously "trafficked" women relies on covering over the reasons why women may foreground the violence of the smugglers and not the violence of the practices leading to their displacement or the violence of state immigration regimes that force them into criminalized routes of migration. For instance, in many countries, including Canada, the state demands of women that they prove their victim status, and often testify in court against the smuggler and secure a conviction against him/her, in order to apply for and receive a special residence permit for trafficked persons. ${ }^{45}$

It is important to stress that presenting one's self as a victim is indispensable for a woman attempting to obtain the right to remain in the country. M any women's stories of ill-treatment at the hands of traffickers need to be understood within the context of thestatehaving criminalized the very activities that both she and the smugglers are engaged in together. For example, given that prostitution is either illegal or not fully decriminalized, a woman can not say that sheknew full well that shewas coming to theU.S. or Canada to work as a sex worker without admitting her guilt at committing a criminal offense. Only by claiming to have been kidnapped, lured, or misled into working as a sex worker can she expect any help from most women's organizations or the state.

Now, no doubt, certain movements of people, particularly undocumented movements, are inculcated with violence. For those migrants who do experience various levels of violencein themigration process, weneed to bevery clear in identifying the factors leading to this. This is not generally what anti-trafficking campaigners do. Two things are often overlooked. First, many recent studies show that in the majority of cases smuggling is a service handled without violence. Indeed, a recent report by the Solicitor General of Canada has acknowledged that migrant smuggling does not have a significant violence generation impact. ${ }^{46}$

The smuggler's role characteristically ends with the delivery of the individual safely to the particular stage of the journey the smugglers are handling. ${ }^{47}$ Indeed, a report by the ILO (2002) discusses how many smuggling operations are “... sometimes difficult to distinguish from legitimate 
work of travel agencies or labour recruitment agencies and may include assisting migrants with obtaining a passport, visa, [and] funds for traveling (travel loans)..." In this regard, the Canadian Council for Refugees has stated that:

[p]eople smuggling, despite its evils, has al so been life-giving. It has made it possible for significant numbers of people to flee persecution and reach a place of asylum when no government was willing or able to offer an escape route. It has allowed them to exercise their human right to seek and to enjoy in other countries asylum from persecution (Article 14, Universal Declaration of H uman Rights). For others, smugglers have offered a way out of a situation of misery and an opportunity for a new life of dignity. Even some of the people who are trafficked, knowing the wrongs of their situation of bondage, may still prefer it to what they left behind, either for themselves or for what it enables them to do for family members. This of course does not in any way justify the abuses perpetrated by the traffickers. But it is relevant to any discussion about solutions to the problem of trafficking. ${ }^{48}$

Yet, all these forms of smuggling have been rendered illegal by the Canadian state. This is in part becausethe word "smuggling," when used to equate symbolically the smuggling of persons with the traditional smuggling of goods, has become devoid of its intricate human element. ${ }^{49}$ This works to conceal precisely those situations where we should insist on knowing why there is a lack of safe alternatives availableto thoseneeding to escapeanumber of (politically, economically, and/or socially) violent situations. The narratives of victimization and criminality within the ideological framework of trafficking, then, organizea contemporary moral panic that discloses the dissymmetry of power relations within a system of Global Apartheid where membership in the North remains elusive for all but a few and are especially restrictive for the majority of people from the South.

Yet, instead of acting on how the clandestine movement of people has its roots in the global capitalist system with its nationalized border control regimes, anti-trafficking campaigns actively look to state authorities to combat and suppress trafficking. Theassumption of theillegal and criminal nature of trafficking or smuggling enables anti-trafficking campaigns to put forward an agenda calling for measures to combat it through heightened border patrols or more punitive measures for traffickers and/or smugglers. Thus, tighter control over the borders, stricter immigration laws, and more punitive criminal laws are called upon as indispensable measures to rescue migrants.

\section{The Standpoint of Undocumented Migrants}

My interviews with twenty-four women from China who were smuggled to the west coast of Canada in the summer of 1999 counter such calls, however. The lived experiences of these women suggest that rather than traffickers and smugglers, the greatest barriers to their equality within the borders of the Canadian national state are national borders, visa regimes, and restrictive immigration regulations whose goal is to criminalize their movements and make them increasingly vulnerable within Canada by classifying them as "illegal." None of the women I interviewed would have qualified for immigration as permanent residents to $C$ anada through the points system, family reunification program, or refugee determination system. These avenues were made completely inaccessible to them.

For all of the women I was able to interview, entering Canada via smuggling systems was the only means of travel and migration. This reflects other studies that show that the majority of "illegal" entrants to countries in the Global North make use of criminalized groups to facilitate their travel. ${ }^{50}$ Unsurprisingly, then, not one of the women I interviewed articulated the demand to "end trafficking." Instead, without exception, the ability to stay in Canada (or the U.S.) legally, to work, make and save wages paid in Canadian (or U.S.) dollars and to be reunited with their family members, either in China or in N orth A merica, were the most consistent demands they expressed.

Y et, many (but not all) migrants' rights activists or feminists active as their closest advocates were unable to fully understand this and incorporate this into their practice. Callsfor punitivemeasuresto further criminalizethesmugglers who helped thesewomen realizetheir survival strategy were often articulated. Any serious questioning of an (im)migration regime that created the conditions for their unsafe journey or their vulnerability once inside Canada was rarely articulated (and when done so, was usually articulated by those critical of the "anti-trafficking" framework). Such responses by activists allows us to see just how anti-trafficking campaigns offer support for more restrictiveimmigration policiesin the nameof exposing the criminal "trafficker" and/or "smuggler."

However, contrary to the idea that women are always forced or coerced by traffickers into illegal migration, many of these women saw the smugglers as the people who most helped them. ${ }^{51}$ Their biggest fear was not of the smuggler but of the Canadian immigration officials who would re turn them to their point of departure, forcing them to start anew their journey for new livelihoods. Being labeled a "trafficked" woman and "reintegrated" back "home" to China was amongst the last things these women wanted. 
Indeed, it appears that the greater coercion faced by these women in their migration journey was being returned. ${ }^{52}$

Significantly, oncethe women interviewed had been captured by the Canadian state, it was imperative for them to claim refugee status rather than claim to know that they were coming to $C$ anada to work as undocumented workers, especially if they cameto work within thesex industry. Once in jail, revealing the reasons for embarking on these journeys to state officials (and by extension to those feminists who could see the sex industry only as a place of violence) would only serve to jeopardize their claim. After all, having a so-called 'bona fide' refugee claim requires that the applicant prove that she has been politically persecuted. Of course, this is more of an indictment of the refugee determination system than of thewomen forced to fit themselves into itsnarrow confines. After all, proving that oneisimpoverished and in desperateneed of a new livelihood does not get a person refugee status in Canada. The majority of the women whom I interviewed were well aware of the severe limitations of the current refugee determination system.

For the minority of women in this group (five out of twenty-four) who either had been sex workersin China and planned to be doing so in North America or for those women who did not work in the sex industry in China but planned to do so in Canada, it was clear that entering this industry was part of their survival strategy. As for the other women who sought other forms of work within capitalist economies, seeking work as a sex worker was a means to an end. For these women, migration to Canada (or the U.S.) for work in prostitution was part of a project designed to lead them out of poverty and a general sense of malaise over their futures. ${ }^{53}$ In my experience as an activist working within a feminist group trying to "help" these women, many of the advocates were unable to accept sex work as part of the women's planned migratory project. Instead, like many anti-trafficking groups, it was insisted that all engagement with the sex trade was violent and coerced and the only reason any of the women migrants would engage in such activities was out of fear of the traffickers/smugglers. ${ }^{54}$

In the end, all of the twenty-four women I had an opportunity to interview were deported from Canada. Because of the highly criminalized character of any subsequent journeys they may embark on, I have not been able to maintain contact with them. Suffice it to say that none of them was happy to be "reintegrated back into their home society" as one would expect of "trafficked" women who had "... by means of the threat or use of force or other forms of coercion, of abduction, of fraud, of deception, of the abuse of power or of a position of vulnerability or of the giving or receiving of payments or benefits to achieve the consent of a person having control over another person, for the pur- pose of exploitation" as the UN Protocol to Prevent, Suppress and Punish Trafficking in Persons, Especially Women and Children would lead us to expect.

\section{Conclusion}

I have shown how, fundamentally, anti-trafficking campaigns serve to enforce nationalized border-regimes and tighten immigration regulations by legitimating the interception and deportation of undocumented migrants. Yet, it is also important to recognize how the "help trafficked victims" approach intersects with the state project of "getting tough on migrants" to shore up the legitimacy of the national state as it continues to aid the operation of global capitalism.

It is, in part, through state categories of illegality that the both the social and legal meaning of "foreigner" is materiaized within Canada. People named as "illegals" become thevery embodiment of theforeigner in that thestateisseen to be legitimate in denying them all the protections and entitlements (labour market and so on) supposedly offered to the citizenry. The deep lack of solidarity across and through national borders manifests itself in such actions, since the state is able to garner great legitimacy in cracking down on "illegal" migrants.

Thus, not only do illegalized workers reap greater profits for employers, they also enablethenational stateto perform its role as the protector of the citizenry. I argue that these are not contradictory phenomena but how the global system of capitalism has been reproduced through the equally global system of national states. Indeed, constructing migrants as "illegal" in the Canadian labour market is part of the rationality of ruling during this period of globalization.

Categories of legal and illegal workers reproduce the rationality of nationalizing labour markets. It helps to make common sense of the notion that the labour market in Canada belongs to Canadians alone. The notion that We ought to have more benefits than Others do is therefore presented as positive, even progressive, and most certainly natural. I argue that this is one of the underlying, yet always implicit, principles of anti-trafficking campaigns and their deep concern that people stay at "home."

Yet, at the same time, anti-trafficking campaigns ostensibly aim to prevent undocumented migrations or "reintegrate" undocumented migrants to their "home" countries. This is not a contradictory phenomenon, however. Instead, the establishment of anti-trafficking campaigns amidst the largest crisis of displacement in documented human history enables the national state to secure a highly vulnerable workforce of "illegals" for employers while allowing the state to present itself as acting for the citizenry. In the process, the state is re-invented as the natural, even demo- 
cratic, body that empowers the nation to act. The security of the national state is assured.

Categories of legality and illegality are, therefore, deeply ideological. They help to conceal the fact that both those represented as foreigners and those seen as Canadian work within the same labour market and live within the same society. Ironically, then, the rendering of certain people as illegalized Others within Canada creates the "cheap" labour force that government and state officials argue they are protecting Us from.

The policy arena of immigration, then, is one of the key avenues for "nation"-building and state formation. Organizing differences between groups of people within the nation-state is a cornerstone of the ongoing importance of state power. In this regard, I argue that growing international movements of capital and people do not create the conditions for the erosion of the state but for its persistence. The recognized right for national states to enforce universally established mechanisms to regulate people's mobility across nationalized borders helps to legitimize state power used against those rendered as Other within the confines of nation-states and weaken those with inferior membership status.

Concepts of citizenship, then, rather than working to progressively expand the rights and entitlements of people living in nationalized spaces, aretheideological cement that holds the repressive power of state practices in place. In regard to the construction of "trafficked victims," citizenship "quietly borrows" from the fictive community of the nation in order to restructure the labour market in Canada.

It is therefore a matter of utmost urgency that we jettison theuse of anti-trafficking discourses and reject the practices that such discourses promote. Instead of calling for greater state intervention in regard to undocumented movements of people embarking on journeys of survival, it is crucial that we see how anti-trafficking measures not only contribute to the criminalization of undocumented migrants but that they also provide a much-needed rationale for "getting tough on illegal migrants."

As it stands, illegalized migrants al ready constitute some of the most vulnerable and exploited people within nationalized labour markets. This reality will not change by assuming that criminalizing migration is tantamount to ending practices of displacement or ensuring safer routes of migration. If we truly wish to end practices of dislocation, make migration safer and end the conditions that make migrants vulnerable in all areas of their lives, we need to shift the focus back to the everyday lived realities of the migrants, especially women and children, that are purportedly being helped by them.
First and foremost, we need to recognize that the label of "trafficked person" "erases many women's active participation in the daily survival of their families and themselves. It renders their labour invisible." 55 W eneed to begin from the standpoint that women migrants, including migrant sex workers, have some agency, even within constrained options. It is precisely by looking at the choices that are taken away and those that are left to undocumented migrants that we can understand the systems of ruling that organize their everyday lived reality. Thus, we need to challenge not only smugglers who move people for personal profits but also capitalist social relations that displace people and render them vulnerable within nationalized spaces.

M oreover, we need to critically examine state practices that are able to legally, and with great legitimacy amongst the citizenry, discriminate against people on the basis of nationality. A nationalist consciousness of "home" is the ideological foundation for organizing contemporary forms of Global Apartheid. Thus, we need to challenge the assumption that "home" is profoundly linked to nationalized territories; that "society" is coterminous with national states. It is the nationalizing of "home" and "belonging" that leads to the acceptance of differential rights and entitlements for people on the basis of whether they are categorized as members or non-members.

As an alternative to anti-trafficking campaigns and as a profound challenge to various apartheids, it is crucial we recognizethat borders havenever worked to contain capital, only people. For example, countries, like Canada, that be lieved, at least rhetorically, in national control over capital investments within its confines, also supported capitalists engaged in imperialist practices outside of its borders. We thus need to reject the notion that border control practices are necessary for the protection of the "nation." Instead, it is necessary that we recognize that they are necessary for the protection and profitability of capital.

The (im)migration regimes of national states are one of the key vehicles through which such competition is organized. Thus, onevery concreteway to strengthen theposition of migrants is to reject the power of the state to differentiate amongst "citizens" and "foreigners" and to determine who can move with rights and who cannot. In other words, we need to extend the field in which we fight for social justice beyond the boundaries of the "nation" and the territorial state. We need to ensure that all persons in the world are equally entitled to the benefits currently enjoyed by an (ever-shrinking) few.

Such demands are the cornerstone of the growing movements of No Borders activists and their networks located throughout and across the Global South and North. In general, such movements have developed an integrated 
politics which accounts for the need to end people's displacement worldwide, to ensure that people are freely able to move and that pro-migrants politics are deeply connected to indigenous peoples' struggles for traditional land and self-determination for all.

Our hopein achieving thesegoals lies in thepower of our imaginations. After all, the most dangerous kind of colonialism is one that colonizes minds as well as bodies. There fore, the strongest, most effective movements against colonialisms are those that are able to clearly imagine a world without the structures, institutions, and consciousness imposed through such practices.

An important example of how a decolonized imagination is mobilized is that of $\mathrm{H}$ arriet Tubman, "conductor" of the Underground Railway. This network of smugglers helped thousands of Black slaves move away from slaveholding regions in the U.S. to the northern U.S. or into Canada. Such a movement of peopleforegrounded thelived realities and demands of enslaved Blacks and rejected both the laws that enslaved them and that restricted others' ability to act in meaningful solidarity with them. Today, Tubman would be classified as a smuggler and, if successfully prosecuted under the 2002 Canadian Immigration and Refugee Protection Act, be imprisoned for life.

I argue that in the struggle to ensure safe passage for migrants the lesson of the Underground Railroad is this: we must support and create our own routes of migration for people needing to move. By lending support to networks for moving people and ensuring their safety, we take the impetus from those who only move people for personal profit. In this we must challenge laws that tell us that smuggling will be punished by life sentences and in some places, such as the U.S., death sentences, ${ }^{56}$ corporal punishment, and huge fines.

\section{Notes}

1. I use "scarequotes" around theterms "trafficking" and "smuggling" to signify that I wish to reader to interrogate, rather than accept, their taken-for-granted character. For the remainder of the paper, however, I will forgo this practice but wish to continue to alert the reader about the problematic assumptions embedded within these terms.

2. "Human Rights Standards for the Treatment of Trafficked Persons," online: International Human Rights Law Group (IHRLG) <http://www.hrlawgroup.org/resources/content/ IHRLGTraffickin_tsStandards.pdf> (date accessed: 13 February 2003).

3. Bob Sutcliffe, "Migration and Citizenship: Why Can Birds, Whales, Butterflies and Ants Cross International Frontiers More Easily than Cows, Dogs and Human Beings?" in M igration and M obility: TheEuropean Context, ed. S. Ghatak and A. Showstack Sassoon (New York: Palgrave, 2001), 67.
4. As I am more interested in discussing how some of the practices of this group were organized through the discourse of "anti-trafficking," the focus of my paper is on this discourse and practice rather than on the specific actions of this one group. I leave this group unnamed because I do not see it as exceptional but rather as typical of those feminist groups that unproblematically accept the ideological frame of trafficking.

5. International Labour Office (ILO), "Getting at the Roots: Stopping Exploitation of Migrant Workers by Organized Crime" (International Symposium, The UN Convention Against Transnational Organized Crime: Requirements for Effectivel mplementation, Turin, Italy 22-23 February 2002), 3.

6. Cynthia Enloe, Bananas, Bases and Beaches: M aking Feminist Sense of International Politics (London: Pandora, 1990).

7. In just one example since 1994, the Canadian government's Export Development Corporation has lent the Chinese government approximately $\$ 200$ million to build the Three Gorges Dam. "Who's Behind China's Three Gorges Dam," online: Probelnternational H omepage <http://www.nextcity/ com/probeinternational'ThreeGorges/who $. \mathrm{html}>$ (date accessed: 19 A pril 2001).

8. Rod M ickleburgh, "China Diverts M ighty Yangtze to Cheers," The Globe and Mail, 10 November 1997; "Who's Behind China's Three Gorges Dam," online: Probe International H omepage <http://www.nextcity/com/probeinternational' ThreeGorges/who .html > (date accessed: 19 A pril 2001).

9. "Major Problems Found in Three Gorges Dam Resettlement Program," online: International Rivers Network <http:// www.igc.apc.org/hric/reports/3gorges.html> (date accessed: April 12, 2001).

10. "Urban Population Continues to Grow," online: College of Earth and Mineral Sciences (EMS), Pennsylvania State University. <http://www.ems.psu.edu/info/explore/U rbanPop.html> (date accessed: 15 February 2003).

11. International Labour Office, "Global Employment Trends," Geneva, 2003, ISBN 92-2-113360-5. 2003.

12. United Nations Population Fund, TheState of W orld Population (New York: UN Population Fund, 2001).

13. Saskia Sassen, The M obility of Labor and Capital: A Study in International Investment and Labor Flow (N ew York: Cambridge University Press, 1988), 15.

14. T. Hatton and J effrey G. Williamson, The Age of M ass M igration: Causes and Economic Impact (Oxford: Clarendon Press, 1998).

15. Bob Sutcliffe, "M igration and Citizenship." To put this into broader historical perspective, it needs to benoted that self-directed emigration from European colonies was banned by colonial powers throughout the nineteenth and much of the twentieth centuries. Of course European colonial powers forcibly moved people from Africa as slaves prior to this period and facilitated the movement of people as "coolie" or indentured labourers from Asia (mostly China and India) throughout the nineteenth century to colonies controlled mostly by the British. 
16. Vandana Shiva, Biopiracy: The Plunder of $\mathrm{N}$ ature and Knowledge (Toronto: Between the Lines 1997), 11.

17. International Labour Office (ILO), "Getting at the Roots: Stopping Exploitation of Migrant Workers by Organized Crime" (International Symposium, The UN Convention Against Transnational Organized Crime: Requirements for Effective Implementation, Turin, Italy 22-23 February 2002).

18. Ibid.

19. N andita Sharma, "'Race', Class and Gender and the M aking of 'Difference': The Social Organization of 'M igrant Workers' in Canada," Atlantis: A Women's Studies Journal (Special Issue: "Whose Canada Is It? Immigrant Women, Women of Colour, Citizenship and M ulticulturalism") 24:2 (Winter 2000b): 5-15.

20. Ibid.

21. Stuart Hall defines a "moral panic" as existing: [w] hen the official reaction to a person, groups of persons or series of eventsis out of all proportion to theactual threat offered; when "experts," in theform of policechiefs, thejudiciary, politicians, and editors, perceive the threat in all but identical terms, and appear to talk "with one voice" of rates, diagnoses, prognoses, and solution; when the media representations universally stress "sudden and dramatic" increases (in numbers involved or events) and "novelty" aboveand beyond that which a sober, real istic appraisal could sustain; then we believe it is appropriateto speak of thebeginnings of a moral panic. SeePaul Gilroy, "There Ain't No Black in theU nion Jack": TheCultural Politics of Race and Nation (Chicago: University of Chicago Press, 1987).

22. Nandita Sharma, "Is Citizenship a Useful Concept in Social Policy Work? Non-Citizens: The Case of M igrant W orkers in Canada," Studies in Political Economy 69 (Autumn 2002).

23. Yasmeen Abu-Laban, "Keeping 'em Out: Gender, Race, and Class Biases in Canadian Immigration Policy," in Painting the $M$ aple: Essays on Race, Gender, and the Construction of Canada, ed. V. Strong-Boag, S. Grace, A. Eisenberg, and J. Anderson (Vancouver: UBC Press, 1998).

24. Nandita Sharma, "'Race', Class and Gender and the M aking of 'Difference': TheSocial Organization of 'M igrant Workers' in Canada."

25. Saskia Sassen, TheM obility of Labor and Capital.

26. N andita Sharma, "'Race', Class and Gender and the M aking of 'Difference'."

27. Nandita Sharma, "The M aking of Citizen Self and N on-Citizen Other: Canada's N on-Immigrant Employment Authorization Programme," in Globalization and Its Discontents, ed. S. M cBride and J. Wiseman (London: M acmillan, 2000a), $129-42$.

28. Anthony Richmond, Global A partheid: Refugees, Racism, and the N ew World Order (New York: Oxford University Press, 1994).

29. Nandita Sharma, "On Being Not Canadian: The Social Organization of 'M igrantW orkers' in Canada," Canadian Review of Sociology and Anthropology 38:4 (N ovember 2001): 415-39.

30. Nandita Sharma, "Is Citizenship a U seful Concept in Social Policy Work?"
31. Bridget Anderson and Julia O'Connell Davidson, "Trafficking: A Demand-Led Problem?" 2003 Report published by Save the Children Sweden, Sida and the Ministry for Foreign Affairs Sweden, online: <www.rse/bookshop > (date accessed: January 15,2003$)$.

32. Nandita Sharma, "TheSocial Organization of 'Difference' and Capitalist Restructuring in Canada: The M aking of 'M igrant Workers' through the 1973 Non-Immigrant Employment Authorization Program (NIEAP)," Ph.D. dissertation, Ontario Institute for Studies in Education at the University of Toronto, 2000).

33. N andita Sharma, "The M aking of Citizen Self and N on-Citizen Other."

34. Bridget Anderson and Julia O'Connell Davidson, "Trafficking: A Demand-Led Problem?"

35. "Presidency Conclusions Leaken European Council," No. 42 as cited in Rutvica Andrijasevic, "The Difference Borders $M$ ake: (II) legality, M igration and Trafficking in Italy among Eastern European Women in Prostitution" in Uprootings/ Regroundings: Q uestions of H omeand M igration, ed. S. Ahmed, C. Castaneda, A. Fortier, and M. Sheller (forthcoming: Berg, 2003).

36. Francois Crépeau, "The Fight against Migrant Smuggling: Migration Containment over Refugee Protection," in The Refugee Convention at Fifty: A View from Forced Migration Studies, ed. J. van Selm et al. (Boston: Lexington Books, 2003).

37. Ibid. Also see International Labour Office, "Getting at the Roots."

38. Cynthia M eillon, "References to Trafficking in theBeijing + 5 Document," in Holding on to the Promise: Women's Human Rights and theBeijing + 5 Review. ed. C. M eillon (N ew Brunswick: Center for Women's Global Leadership, 2001).

39. Bill C-11, Article 117:3; Crépeau, "The Fight against M igrant Smuggling."

40. Ibid.

41. Deborah Brock, Kara Gillies, Chanelle Oliver, and Mook Sutdhibhasilp, " M igrant Sex Work: A Roundtable Analysis," Canadian Woman Studies 20:2 (2000), 87.

42. Ibid.

43. Andrijasevic, "The Difference Borders M ake."

44. Scenes for instance where a person identified as previously "trafficked" is asked to relive her experiences, to denounce trafficking in order to convinceaudiencemembers of theneed to support a particular organization's anti-trafficking (and usually anti-prostitution) campaign or even when she is not asked to speak to her experiences of being "trafficked" but to talk about how she became active in "anti-trafficking" measures.

45. Ibid.

46. As cited in Crépeau, "TheFight against M igrant Smuggling." 47. Ibid.

48. "M igrant Smuggling and Trafficking in Persons," online: $\mathrm{Ca}$ nadian Council for Refugees Homepage <http://www.web. net/ ccr/traffick.html> (date accessed: 20 February 2000). 
49. Crépeau, "The Fight against M igrant Smuggling."

50. International Labour Office, "Getting at the Roots," 2.

51. This was also found by Ko-Lin Chin, Smuggled Chinese: Clandestinel mmigration to theU nited States (Philadel phia: Temple University Press, 1999).

52. Seelbid. for a discussion on how many "returned trafficking victims" almost immediately renew their attempts to secure jobs in the Global North soon after being returned.

53. Andrijasevic, in "The Difference Borders M ake," came to a similar conclusion in the context of sex workers migrating to certain European countries.

54. Tellingly, an "employment committee" established by some feminist advocates working with these women tried to place some of thewomen living outside of the prisonsin jobs within thegarment industry. One of theleast paid occupations within Vancouver, this was seen by these advocates as a viable alternative to the sex industry for these women migrants.

55. Brock et al, "M igrant Sex Work."

56. Ko-Lin Chin, Smuggled Chinese.

N andita Sharma is an assistant professor in the Department of Sociology and Anthropology at the U niversity of Windsor, O ntario, Canada. She is also a co-founder of O pen the Borders!, a group committed to seeking justice for migrants.

(C) Nandita Sharma, 2003. This open-access work is licensed under a Creative Commons Attribution-NonCommercial 4.0 International License, which permits use, reproduction and distribution in any mediuf 9 for non-commercial purposes, provided the original author(s) are credited and the original publication in Refuge: Canada's Journal on Refugees is cited. 